\title{
Maria, Maryjka, Maryja. Figura intymizacji Gardzienic w kobiecym dyskursie "Gardzienic"1
}

\section{Abstract}

\section{Maria, Maryjka, Maryja. The Intimacy Figure of the Gardzienice on the Female Discourse of the "Gardzienice"}

The article presents an analysis and an interpretation of the story of Maria of Gardzienice, a local folk artist: an embroiderer, a painter and a specifically understood performer, now deceased, but also forgotten during her life and living alone in the village near Lublin. This story has been told by „an actress" from „the "Gardzienice» Theatre" in the course of my fieldwork in Gardzienice village on the 30th of June 2012. During this field interview, a unique in its lyrical formula, a symbolic and a creative spiritual biography of Maria of Gardzienice was established. This story creates a specific „apocrypha” of femininity understood as an aesthetic lifestyle of a creative women, a socially self-excluding ,artist" - an amateur, wanting to create outside the patriarchal community of the village. Maria, a real woman from the village, in the story of the „actress from „the «Gardzienice» Theatre" appears at the same time as: Maryjka - a goddess and Mary - the Blessed Virgin Mary. This story is the figure of an intimacy female discourse of Gardzienice village on” „the «Gardzienice» Theatre”. It constitutes a symbolic escape into the mythologisation of femininity as a creative response of the women from Gardzienice village and the women from "the "Gardzienice Theatre»" on the local social conflict between "the village” and "the Theatre”. The „actress „ who verbalises this story, makes a symbolic identification with Maria - the "artist” from the Gardzienice village and in this way essentialistically formulated femininity is a symbolic way of escapism of the women from the local conflict.

Keywords: discourse, essentialism, femininity, social conflict, locality.

${ }^{1}$ Artykuł powstał dzięki środkom finansowym z funduszu Stypendium „Start” Fundacji na rzecz Nauki Polskiej. 


\section{Konflikt „Gardzienice” versus Gardzienice. Kontekst społecznej struktury apokryfu}

Niniejszy artykuł, napisany dzięki kobiecym opowieściom o „Gardzienicach”-,,Teatrze”, a więc o Europejskim Ośrodku Praktyk Teatralnych założonym i prowadzonym przez Włodzimierza Staniewskiego oraz wsi Gardzienice, gdzie usytuowany jest ten ośrodek, odtwarza apokryficzną strukturę opowieści o gardzienickiej wiejskiej artystce amatorce Marii Szutko, zmarłej w 2011 roku. Świadomie używam tu pojęcia apokryfu, gdyż osoba ta funkcjonuje w opowieściach, zarówno tych przytoczonych $w$ artykule, jak i innych, niezinwentaryzowanych nagraniami terenowymi jako postać z pogranicza życia codziennego i bliżej niedookreślonej sfery sacrum. Oddając skalę jej społecznej mitologizacji, wybrałam zatem (ugruntowane teologicznie i literaturoznawczo) pojęcie apokryfu. W sytuacji opisu fenomenu Marii Szutko badacz lub badaczka, choć z moich doświadczeń terenowych wynika, że biologiczny mężczyzna nigdy dotąd nie został dopuszczony do spektrum tych opowieści, z etycznej konieczności - staje się nośnikiem apokryfu. Usiłując bowiem wypowiedzieć historię społeczną tej biografii bez szacunku dla jej warstwy symbolicznej, głęboko przeżywanej przez Opowiadaczki, uzyskalibyśmy jedynie nieco arogancką - wobec emocjonalnej perspektywy badanych - relację o starej, opuszczonej kobiecie usiłującej tworzyć różnego rodzaju artefakty kulturowe, od rękodzieła po utwory literatury ustnej i pieśni (nigdy niespisane) i która inscenizowała własną śmierć jako zaśnięcie, a czasem gościła w swym wiejskim domu przeżywające różnorodne kryzysy biograficzne „aktorki "Gardzienic»". Obraz taki nie byłby jednak prawdziwy społecznie, bo żadna z moich Rozmówczyń nie uważała Marii Szutko za osobę o deficytach psychicznych lub społecznych. Przeciwnie, artystyczna identyfikacja z tą postacią z lokalnych Gardzienic była w tych opowieściach niezwykle jednoznaczna. Niewątpliwie skala mitologizacji owej postaci jest skrajna, to znaczy w obrazie społecznym, werbalizowanym opowieściami o Marii Szutko, znacznie więcej jest prawdy psychologicznej samych Opowiadających niż (niemożliwej do weryfikacji) samoświadomości bohaterki tych opowieści. I właśnie w tej kluczowej dysproporcji kryje się fenomen społeczny Marii Szutko z Gardzienic, którego apokryficzność jest markerem szerszej i znacznie bardziej złożonej mitologizacji Gardzienic-„,Wsi” (Kapusta 2015) i „Gardzienic”-„Teatru”. Konflikt społeczny na linii „Teatr” - „Wieś” funduje [poprawnie jest ufundowuje, funduje oznacza coś innego] trwałość fenomenu „Gardzienic”. W centrum tego konfliktu jest usytuowany fantazmat „człowieka wsi” - „człowieka gardzienickiego” (Kapusta 2013) i symetrycznie mu odpowiadający wizerunek „aktorów”. Odtwarzanie się tego konfliktu jest warunkowane wieloma czynnikami, jednak niezmienne pozostaje w nim poczucie wywłaszczenia mieszkańców Gardzienic z ich miejscowości przez lidera „Gardzienic” - Włodzimierza Staniewskiego. W konflikcie tym osoba Marii Szutko odgrywała symboliczną rolę 
instytucji eskapistycznej, osoby-ucieczki, w której kobiety, zarówno te z „Teatru”, jak i „Wsi” poszukiwały słuchaczki, powierniczki i doradczyni. W Marii Szutko lokowane były potrzeby poczucia bezpieczeństwa, ładu i alternatywnego porządku świata. Stąd także, nawiązująca do tradycji literatury ustnej, forma apokryfu w kluczowej dla niniejszego studium kobiecej relacji o Marii Szutko. Jest to rzeczywistość opowieści sui generis i arogancja wobec niej nakazująca poszukiwać innego niż emiczny języka opowieści, a więc poszanowania duktu literatury ustnej, którą są opowieści o Marii, byłaby tu nie tylko anachroniczna i prezentystyczna, ale - po prostu - nieetyczna. Świat opowieści jest bowiem światem prawdy psychologicznej jednostki i należy się mu należyta uwaga. Bez tej postawy nie ma relacji terenowej.

\section{Od Marii do Maryjki. „Indie" w Gardzienicach: intymistyczna ekspresja kobiecości}

Kobieta²: (...) Y ... czym są Gardzienice? Są taką wartością też bardzo duchową, głęboką, piękną. Ja nie jestem katolikiem, są mi bliższe inne sfery - wschodnie, buddyzm konkretnie, natomiast mnie w ogóle fascynują Indie i hinduizm też w sferze takiej już bardziej teoretycznej. I wielokrotnie byłam w Indiach, oglądałam wiele niezwykłych żywych rytuałów, które są malownicze, pełne kwiatów, smaków, zapachów, to jest feeria barw, kolorów, po prostu orgia form. Ale to, co zobaczyłam dzięki takiej pani [imię i nazwisko - kod A.K.], co ta bardzo pobożna, wspaniała kobieta uprawia pod swoim kasztanem przed domem, to... to była furtka do tego, żeby docenić, że ja też skądś pochodzę i u nas są też naprawdę konkretne Indie i konkretne fajerwerki. Tutaj jest cudowny kult Maryi, która jest boginką $\mathrm{i}$ ja uwielbiam Maryję. Mam Maryję w swoim ogródku w pniu drzewa, nie zainstalowałam jej tam osobiście, zainstalowała ją tam pani, od której ja kupiłam ten dom, ta Maria rośnie razem z tym drzewem, w dziupli siedzi, jest fantastycznym błękitnym duchem. I pani Maria co niedzielę odprawiała swoje msze: wychodziła na krzesło, przed dom, siadała pod kasztanem na krzesełku, stawiała na kolanach albo na stoliczku obok radyjko kasetowe, do którego wkładała kasetę, miała ich trzy, dwie były wspaniałe, jedna była koszmarna. I zawsze kiedy dochodziło do tej trzeciej, to ja po prostu zaczynałam pękać w szwach i całe moje rozanielenie i tolerancja gdzieś zaczynało nagle fermentować, ale na szczęście po tej trzeciej kasecie zawsze przychodziła pierwsza, jak się okazało później, zawierająca nagrania sprzed siedemnastu lat pani Marii osobiste, gdzie piękne śpiewy do Marii Matki Boskiej, pięknym sopranem rozwibrowanym jak ptaki czynione, no to wydobywały się właśnie z jej gardła. Pani Maria z tym radyjkiem w okoleniu kwiatów, które w późniejszym etapie jej życia stały się sensem dla niej i ona stanowiła sama Marią będąc, ubierając się zawsze na błękitno - kolor, który kochała, po prostu w okoleniu tych kwiatów żywych, plastikowych, tych pieśni, to była jakaś ikona kompletna. Ona hodowała swoją Maryjkę po drugiej stronie szosy, miała taką swoją Marię Matkę Boską, własny ołtarz i to

${ }^{2}$ Wywiad z dnia 30 czerwca 2012 r. przeprowadzony przeze mnie z „aktorką” ,Teatru «Gardzienice»” w Gardzienicach. Wszystkie cytowane fragmenty pochodzą z tego wywiadu (jego transkrypcji), a podkreślenia w cytatach ode mnie. 
był kolejny sens jej życia, ponieważ Matkę Boską trzeba było umyć, ubrać, właściwie chyba nakarmić, napoić i okwiecić kwiatami na każde święto inaczej. (...) (Kobieta 2012, wywiad) ${ }^{3}$

\title{
Od Maryjki do Maryi. Maria z Gardzienic: „apokryf” kobiecości wniebowstępującej
}

\begin{abstract}
Anna Kapusta: (...) Dopowiadamy jeszcze coś?
Kobieta: Historię o pani Marii, bo warto. Pani [Imię i nazwisko - kod. A.K.] w maju zeszłego roku zaczęła się robić półprzezroczysta pomalutku. To wszystko odbywało się w atmosferze niezwykle pięknej sielanki: właśnie te majowe niedziele przecudownie okraszone słońcem, spokojem, brzęczącymi owadami ponad łąką, nad którą ona mieszkała. Siedząc na krzesełku przed swoim domem, widząc tą łąkę, oglądając każdego dnia, ona zaczęła robić się przezroczysta i to, my już instynktownie czuliśmy, że ona umiera, ale ona była tak cudownie rozkochana i zachwycona tym stanem, że to było coś bardzo natchnionego i bardzo napawającego bezpieczeństwem. I nie zapomnę tego obrazu, kiedy ona ubrana w błękitny fartuch w ogromne białe grochy szła przez łąkę w blasku słońca, przez łąkę przekwitniętych dmuchawców - białych kulek puchatych, puszystych jak te grochy na tym jej błękitnym fartuchu, z błękitem nieba ponad nią i z tym puchem siwych włosów ściętych na mniszka. I ja patrząc na nią, zdałam sobie sprawę, że ona, ta Maria idąca przez łąkę tych dmuchawców, latawców, wiatrów, ona idzie do nieba, ona jest już przezroczysta, ona jest błękitna, ona jest już leciutka jak ten mniszek lekarski. I ona szła przez tą łąkę w stronę mojego domu, mniszki przed... przed jej stopami ulatywały do nieba i leciały, i ona szła tak lekko, tak pięknie, taka szczęśliwa, rozpuszczając się w poranku tej majowej niedzieli. To był absolutnie święty obraz, Święta Mario, laskiś pełna. (Kobieta 2012, wywiad)
\end{abstract}

\section{„Aktorka” i „artystka”. Kobiecość Gardzienic i kobiecość „Gardzienic". Utożsamienie}

Kluczowa opowieść, której poświęcę niniejszą analizę, powstała jako indywidualna relacja z dziesięcioletniego procesu doświadczania społecznej: realnej i symbolicznej przestrzeni wsi Gardzienice, zwerbalizowanego przez „aktorkę” pracującą w „Teatrze «Gardzienice»” w Gardzienicach, a werbalizacja ta nastąpiła w trakcie wywiadu terenowego, udzielonego mi przez ową kobietę w Gardzienicach w dniu 30 czerwca 2012 roku. Opowieść, którą przytoczę, była częścią odpowiedzi na moje pytanie otwarte: „Czym są dla Ciebie «Gardzienice» jako «Teatr» i Gardzienice jako «Wieś»?" Opowieść została wypowiedziana wobec mnie w (przemil-

3 Kobieta, około 30-40 lat, przytaczam powyżej wypowiedzi w trakcie wywiadu w Gardzienicach (oba cytaty-motta). 
czanym w niej ${ }^{4}$ ) społecznym spektrum lokalnego konfliktu, wiążącym chroniczną, konfliktową relacją społecznych zależności współbytowanie „Teatru” i „Wsi”, trwające w Gardzienicach od 1977 roku aż do chwili obecnej. Ten lokalny konflikt społeczny tworzy podstawowe tło dla indywidualnej ${ }^{5}$ figury intymizacji dyskursu, czyli wyodrębniona tu analitycznie przeze mnie figura dyskursu jest jego integralną częścią i pochodną. Dyskurs społeczny tego konfliktu zaowocował bowiem swą intymistyczną, indywidualną figurą (Marii/Maryjki/Maryi), którą "aktorka” ofiarowała mi w trakcie wywiadu. Mówiąc: ofiarowała, podkreślam intymistyczny charakter tego szczególnego aktu wypowiadania kobiecości „aktorki”, w którym jako badaczka - wówczas uczestniczyłam. Lokalny chroniczny konflikt społeczny zinternalizowany jest w tejże indywidualnej figurze dyskursu intymistyczną wizją świata społecznego, którego doświadczyła i który zintegrowała kobieta w porządku symbolicznym swej biografii. Świat społeczny „Wsi” stał się w jej opowieści ekspresją wizerunku Marii': gardzienickiej „artystki” ludowej ${ }^{7}$, będącej zarazem indywidualnym i społecznym centrum tego świata, spersonalizowanego doświad-

${ }^{4}$ W wywiadzie „aktorka” powiedziała wprost, iż nie chce uczestniczyć swą opowieścią w konflikcie „Gardzienice”: „Teatr” versus Gardzienice „Wieś”. Oto jednoznaczna deklaracja: „Gardzienice dla mnie są domem przez duże «D» i to ten miks: «teatr» $\mathrm{i}$ «miejsce». Ja też, ja nie chciałabym wchodzić w ten temat, jak nas wieś traktuje, bo to jest temat rzeka, ja też bardzo kocham wielu ludzi tutaj".

${ }^{5}$ Tworzę tu celowo zbitkę pojęciową: indywidualna figura intymizacji dyskursu społecznego, aby zaakcentować jednostkowość prezentowanej opowieści, a jednocześnie uwzględnić jej społeczne odniesienia, które złożyły się na indywidualne doświadczenie (tu - rozumienie bycia twórczą kobietą przez „aktorkę”: poszukiwanie kobiecości i jej sakralnych wymiarów w różnorodnych tradycjach kulturowojęzykowych: buddyzm, hinduizm, katolickie kulty Maryjne). Fakt społeczny, iż współczesna intymność (pomimo znacznej indywidualizacji i prywatyzacji tej sfery) nie jest nadal indywidualną i jednostkową figurą dyskursu społecznego, a - jak to bywało przed współczesnymi formacjami społecznymi późnej nowoczesności - jednostka zwykle jedynie reprodukuje zbiorowe schematy intymności, kategorycznie zdiagnozował w swym dziele Anthony Giddens (Giddens 2007).

${ }^{6}$ Maria, osoba będąca bohaterką tej opowieści, zmarła w 2011 r. W tym opracowaniu nie podaję i nie analizuję Jej szczegółów biograficznych i koduję Jej dane osobowe jako jednej z moich badanych (przeprowadziłam z Nią kilka rozmów i wywiad w dniu 20 lutego 2011 r.). Rodzina zmarłej Marii wyraziła zgodę na osobne opracowanie Jej indywidualnej i twórczej biografii jako dzieła życia samorodnej „artystki”, które powstanie jako oddzielna monografia mojego autorstwa w przyszłości, z uwzględnieniem materiału przekazywanego mi już stopniowo przez Rodzinę Marii.

7 Pojęcia „artystka” ludowa używam w tym miejscu jedynie roboczo, mając świadomość, iż obniżam rangę niezwykle zindywidualizowanej i oryginalnej twórczości Marii. Cudzysłów sygnalizuje w mojej intencji brak statusu profesjonalnego (brak formalnego wykształcenia artystycznego) Marii, aczkolwiek w mojej ocenie Maria była pełnoprawną artystką poprzez swe praktyki twórcze i dzieła jako autorka dzieł artystycznych (obrazy olejne, pastele, haftowane, wyszywane poduszki i obrusy, ołtarzyki domowe i wiele innych). Podobny (nieprofesjonalny) status „aktorki” podziela również „aktorka” udzielająca mi wywiadu. Obie kobiety są więc - w szerszym planie społecznym - artystkami poprzez swe praktyki artystyczne, czyli poprzez biograficzną, indywidualną decyzję o tworzeniu wraz z ryzykiem wykluczenia jako „nie-profesjonalistki”. Analogia ta jest znacząca symbolicznie w kontekście utożsamienia się „aktorki” z „Gardzienic” z „,artystką” z Gardzienic i stanowi istotny rys społeczny charakteryzowanego fenomenu. 
czeniem kobiecości innej kobiety, bowiem prezentowana opowieść ufundowana jest na symbolicznym utożsamieniu „aktorki” z „artystką” ludową z Gardzienic. Symboliczne centrum tego świata społecznego to realna osoba kobiety - „artystki” z Gardzienic - zmarłej w listopadzie 2011 roku, zinterpretowana przez „aktorkę” jako metafora jej własnej, kobiecej duchowości ${ }^{8}$. W swoistym rytuale werbalizacji tejże opowieści „aktorka” doświadcza „Wsi” poprzez tę konkretną osobę „artystki” z Gardzienic, czyniąc ją zarazem i metonimią „Wsi” (Gardzienice to Maria: symboliczna redukcja), i metaforą indywidualnego doświadczenia „aktorki” (Maria to twórczość: symboliczne rozszerzenie). Ta eskapistyczna - wobec konfliktu społecznego - wizja kobiecości „Wsi” stanowi niezwykle wyrazisty przykład kobiecego utożsamienia $\mathrm{z}$ intymną kobiecością innej kobiety, doświadczanego przez „aktorkę” w lokalnym konflikcie społecznym. Kobiecość „Wsi” to jej osobowa manifestacja w specyficznej sztuce życia i umierania ludowej „artystki”, którą konstruuje (dookreśla symbolicznie) wypowiedziana wobec mnie opowieść, będąca de facto autokomunikacją ${ }^{9}$ „aktorki” w specyficznej strukturze symbolicznej dawania świadectwa biograficznego. W tej perspektywie internalizacja konfliktu Gardzienice versus „Gardzienice” w jego kobiecej recepcji okazuje się właśnie jednostkową intymizacją dyskursu konfliktu społecznego, transformowanego $\mathrm{w}$ indywidualnej opowieści w symboliczną, kobiecą figurę intymizacji doświadczenia. Wyodrębniona tu więc przeze mnie figura intymizacji jest w opowieści dwuetapowa i dynamiczna: Maria-,,artystka” transformuje się początkowo z Marii-realnej kobiety z Gardzienic w Maryjkę-boginkę, wreszcie zaś w Maryję-Matkę Boską, jest więc ona najpierw Marią - uosabiającą boginkę, a następnie Marią - manifestującą się Matką Boską. W obu przypadkach realna Maria transformowana jest kolejno w opowieści w symboliczną Maryjkę i Maryję, czyli to nie Maryjka przekształca się bezpośrednio w Maryję, ale właśnie symboliczna Maria, jako potencjał i Maryjki, i Maryi, uosabia dwukrotną przemianę symboliczną realnej kobiety, zwerbalizowaną w trójpostaciowej, procesualnej postaci charakterystycznej dla symbolicznego kompleksu Bogini Matki, uniwersalnego kulturowo w ciągu róż-

${ }^{8}$ Używam pojęcia „duchowości” w jego szerokim ujęciu, nie wdając się tu w dyskusje o tym, czy duchowość indywidualna współczesnych ludzi pozostających poza instytucjonalnym wyznaniem religijnym to forma nowej duchowości, prywatyzacji religii czy też religijności typu ludowego przekształcającej się w formułę religii przeżywanej. Przyjmuję ogólne rozstrzygnięcie terminologiczne wypracowane przez Katarzynę Leszczyńską i Zbigniewa Paska: „Pojęcie «duchowość» ma charakter interdyscyplinarny. Jego współczesna kariera ściśle wiąże się z przemianami religijności, z procesami sekularyzacji i prywatyzacji sfery religijnej człowieka" (Leszczyńska, Pasek 2008: 9).

9 Mam tu na myśli fakt społeczny rytualnej „aktywacji znaczenia” - jak to nazywał Roy Rappaport - w samej już pozytywnej decyzji o wypowiadaniu opowieści przez badaną wobec badaczki, kiedy to konstytuował się swoisty rytuał wypowiadania siebie, bo werbalizowanie własnej opowieści jest w pierwszym wymiarze komunikowaniem jej sobie, dopiero potem słuchaczce czy słuchaczowi. Osobny wątek stanowi terapeutyczny potencjał głośnego wypowiadania doświadczeń autobiograficznych, który jedynie tu sygnalizuję. Na temat komunikacyjnych wymiarów rytuału - zob. Roy Rappaport (2007: 159-198). 
nych epok i formacji kulturowych, w którym inicjacja kobieca stanowi przedmiot kobiecej autorefleksji (Szyjewski 2008: 457-474). Opowieść ta odsłania unikatowy, kobiecy rys lokalnego konfliktu gardzienickiego i manifestuje biograficzne zanurzenie „aktorki” w poszukiwanie jej własnego dyskursu kobiecości. Kobiecy rys intymizacji oznacza tu zatem społeczną dynamikę internalizacji konfliktu poprzez jego indywidualną intymizację, ufundowaną na utożsamieniu z konkretną, realną kobietą, a zarazem $\mathrm{z}$ wyabstrahowaną z tego doświadczenia abstrakcyjną, zesencjalizowaną ${ }^{10}$ kobiecością. $W$ tym procesie społecznym zachodzi przyswojenie dezintegracyjnego doświadczenia konfliktu jako integrującego centrum intymnego utożsamienia kobiety z potencjałem twórczym innej kobiety. Inaczej mówiąc: kobieta („aktorka”) mitologizuje kobiecość innej kobiety („artystki”), adaptując się do chronicznej sytuacji napięcia społecznego w lokalnym konflikcie, na którego przebieg i dynamikę oraz społeczne skutki nie miała ona żadnego wpływu. Innymi słowy: $\mathrm{z}$ powodu braku decyzyjności w realnym konflikcie społecznym wycofuje się ona na pozycję symbolicznego poszukiwania, esencjalistycznie pojmowanej kobiecości poprzez utożsamienie z kobietą-,,artystką” ze wsi Gardzienice. Ten społeczny mechanizm eskapistyczny charakteryzuje kobiecy dukt konfliktu „Gardzienice”: „Teatr” - Gardzienice: „Wieš, a opowieść tu analizowana wyraża egzemplarycznie jedynie jego szersze, zwykle niezwerbalizowane konteksty, bo kobiety i ich opowieści o relacji „Gardzienice” versus Gardzienice istnieją ukryte w mówionym dyskursie „Gardzienic” w Gardzienicach i trzeba dostać klucz do intymistycznego świata internalizacji tego konfliktu wraz z prawem do uczestniczenia w wypowiadaniu opowieści, aby uchwycić owe figury intymizacji dyskursu Gardzienic: „Wsi” w dyskursie „Gardzienic”: „Teatru”. Ważnym elementem tego klucza do opowieści jest esencjalne ${ }^{11}$ bycie kobietą w przypadku badaczki społecznej i być może dlatego dyskurs intymizacji Gardzienic, ukryty w dyskursie konfliktu społecznego w Gardzienicach wraz z indywidualnymi, intymistycznymi figurami tego dyskursu nie istnieje jako jawny w mówionym dyskursie na terenie wsi Gardzienice ani w żadnej dotychczasowej literaturze przedmiotu dotyczącej "Gardzienic". Odsłaniam go zatem w filtrze tej właśnie opowieści, zdając sobie

${ }^{10}$ Celem tego artykułu nie jest teroretyczny przegląd setek koncepcji esencjalizmu w humanistyce, dlatego też poprzez esencjalizację rozumiem: biologiczną, redukcyjną koncepcję kobiecości, wynikającą z analizowanych opowieści. Nie wchodzę w dyskusje z irrelewantnymi wobec problemu opowieści dywagacjami o „esencjalizmach”.

${ }^{11}$ Esencjalizacja ta była wielowymiarowa i dotyczyła ona najpierw bycia biologiczną, następnie heteroseksualną kobietą w podobnym wieku jak badana, jak udało mi się wyinterpretować ze stylu kontaktu terenowego, choć komunikaty te - jak to w dyskursach intymistycznych bywa - identyfikowałam na pograniczach ich werbalizacji. Być może istnieje więc nadal w tego typu dyskursach ukryte, esencjalistyczne kryterium kontaktu terenowego i należy je brać pod uwagę, konstruując podobne sytuacje badawcze. Inaczej materiał nie zostanie w ogóle uzyskany albo będzie znacząco niepełny. 
sprawę z esencjalizującego ujęcia kobiecości, które tu przyjęłam ${ }^{12}$, respektując własną regułę przymierza terenowego, czyli w tym przypadku mam świadomość,

${ }^{12} \mathrm{~W}$ trwających od lat 70. aż do dziś dyskusjach o esencjalizmie i konstruktywizmie w koncepcjach wymiarów płci biologicznej i kulturowej esencjalizm jest określeniem zdecydowanie pejoratywnym i postrzeganym jako dyskryminacyjny model objaśniania zjawisk społecznych w zakresie badań nad gender. Anna Burzyńska tak podsumowała oceny stanowisk esencjalistycznych na gruncie gender i queer studies: „W ciągu lat siedemdziesiątych i osiemdziesiątych kategoria gender stała się jedną z najczęściej używanych, zwłaszcza w anglojęzycznych dyskursach feministycznych (w szczególności Kate Millet, Germaine Greer i Gale Robin). Wkrótce też zaczęto się spierać o relacje pomiędzy płcią biologiczną a płcią społeczno-kulturową, a także debatować, która z nich (w wypadku gdy uznaje się, że istnieją obydwie) odgrywa ważniejszą rolę, w procesie tworzenia się tożsamości człowieka. W niedługim czasie wyodrębniły się co najmniej trzy stanowiska wypracowane w kontekście kategorii gender: - w myśl pierwszego z nich (najrzadszego) - esencjalistycznego (zwanego także biologistycznym lub naturalistycznym) - nadal uznawano płeć biologiczną za absolutnie niepodważalną podstawę, decydującą o różnicach między ludźmi, a także za czynnik silnie determinujący, a nawet przesądzający o ich tożsamości i o ich funkcjonowaniu w przestrzeni społecznej; ustanowiono też zależność przyczynową: płeć biologiczna jest pierwotną przyczyną, płeć społeczno-kulturowa - skutkiem./ W myśl drugiego stanowiska przyjęto rozwiązanie kompromisowe: uznano, że płeć biologiczna jest wprawdzie pierwotna, niemniej jednak płeć kulturowa pełni o wiele ważniejszą funkcję w procesie konstruowania tożsamości;/ - W myśl trzeciego - radykalnie konstrukcjonistycznego i równie skrajnego jak pierwsze - zrezygnowano całkowicie z koncepcji uwarunkowań biologicznych, uznając, że jedynie gender, kształtujący się w toku społecznych interakcji, odgrywa konstytutywną rolę w tworzeniu się tożsamości podmiotowej./ Ostatecznie spory wokół pierwszeństwa roli płciowej (biologicznej czy kulturowej) spolaryzowały się w latach osiemdziesiątych do trwającej nadal dyskusji między obozem esencjalistycznym (naturalistycznym) i konstrukcjonistycznym. Przedstawicielki i przedstawiciele opcji pierwszej opowiadali się za uniwersalnymi, biologicznymi, poprzedzającymi uwarunkowania społeczne i kulturowe czynnikami płciowymi, wpływającymi na kształt wtórnego wobec nich gender, czynnikami płciowymi za podstawę uznając uniwersalną „naturę kobiety”. Zwolenniczki i zwolennicy stanowiska przeciwnego - na które bardzo mocno wpłynęły tendencje marksowskie, jak i psychoanalityczne, a także zdecydowanie antyesencjalistyczne nurty filozofii ponowoczesnej (zwłaszcza we Francji i w Stanach Zjednoczonych) oraz teorie konstrukcjonizmu społecznego - stanowczo zaprzeczali istnieniu jakichkolwiek substancjalnych, uniwersalnych i niezmiennych cech, które mogłyby rozstrzygnąć o przynależności człowieka do określonej płci społeczno-kulturowej” (Burzyńska 2006: 448-449). Z moich doświadczeń terenowych, w tym opisywanej sytuacji społecznej pozyskania opowieści, w której kluczem była tu moja płeć biologiczna, bo „aktorka” opowiadała mi o swoim doświadczeniu jako kobiecie, wynika inna obserwacja esencjalizacji sytuacji badawczej oraz esencjalistycznego języka opisu i interpretacji, który prezentuję. Nie uważam, że istnieje jakakolwiek uniwersalna „natura kobiety” lub wspólnota „kobiecego doświadczenia” i nie zgadzam się z niebezpiecznym społecznie ideologizowanym potencjałem redukcji kobiety do jej wymiaru biologicznego, ale w swojej pracy terenowej zauważyłam, iż w sytuacji kryzysowej, jaką niewątpliwie jest wypowiadanie własnych doświadczeń biograficznych/duchowych wobec badaczki, zachodzi niejako zjawisko rytualnej redukcji w utożsamieniu typu kobieta-kobieta, w którym poziom biologiczny utożsamienia wyprzedza znacznie płeć społeczno-kulturową. Być może jest to jeden z wielu atawizmów kulturowych, by tak rzec: archaiczny dukt mówienia przez kobietę o kobiecości do kobiety, będący dalekim echem znaczenia wspólnot kobiecych w budowaniu więzi społecznych. Fenomen ten wymagałby oddzielnego projektu badawczego, by pełniej określić, jak zachodzi ten proces w jego szczegółach, niemniej jednak płeć biologiczna jest tu niezwykle wyrazista w swej integracyjnej roli i niezastępowalna żadną badawczą ani interpretacyjną strategią konstruktywistyczną, bo opowieść od owej kobiety otrzy- 
że mogłam zostać obdarowana ową opowieścią dlatego właśnie, że jestem biologiczną kobietą. Ten oto esencjalistyczny fakt społeczny otworzył moją terenową ścieżkę kontaktu badawczego jako świadka opowieści obdarzonego zaufaniem snucia opowieści w mojej obecności. W polskojęzycznym uniwersum symbolicznym wypowiadania opowieści biologiczna kobieta jest prawdopodobnie (jak udało mi się stwierdzić w swobodnych rozmowach z innymi czynnymi badaczami i badaczkami terenowymi) jedyną możliwą odbiorczynią intymnej opowieści innej kobiety, co sprawia, że symboliczne utożsamienie płci biologicznej (sex) ciągle wyprzedza w tym kontekście płeć kulturową (gender) ${ }^{13}$, dlatego pisząc tu słowo kobiecość, nie ujmuję go w poprawny genderowo cudzysłów, sugerujący konstruktywistyczny koncept gender ${ }^{14}$, bo model komunikacji kobieta-kobieta zaistniał w opisywanym tu przypadku jako esencjalistyczny paradygmat kobiecości (kobieta mówiq̨ca do kobiety) i jest to jego wierna charakterystyka, oddająca ekologię wywiadu terenowego, czyli respektowanie świata doświadczeń wypowiadającej się w tej opowieści kobiety.

\section{Internalizacja konfliktu: intymizacja konfliktu}

Opowieść będąca indywidualną figurą intymizacji Gardzienic w mówionym dyskursie "Gardzienic” wizualizuje kobiecy dukt konfliktu społecznego na linii „Teatr”-„Wieś”. Wizualizacja ta zachodzi w regule internalizacji konfliktu polegającej na jego intymizacji. Chodzi mi tu o sytuację społeczną, w której kobieta, nie mając - w jej przekonaniu - żadnej możliwości wpływu społecznego na lokalny konflikt, wycofuje się symbolicznie w intymistyczny, wewnętrzny świat społeczny i w tej intymnej rzeczywistości doświadczenia reprodukuje kulturowe kody symboliczne, przyswojone przez nią w realnym porządku biografii. W ten oto sposób

małam najpierw jako kobieta, dopiero potem jako młoda kobieta, a na końcu dopiero jako badaczka, do której „aktorka” miała duże zaufanie.

${ }^{13}$ Podział płci na jej podstawę biologiczną (sex) i jej kulturową interpretację (gender) przyjmuję za Robertem Stollerem, uzupełniając ten właśnie koncept podziału o moje własne, ugruntowane praktyką terenową przekonanie, iż w sytuacjach kryzysowych (do których zaliczam społeczną sytuację wypowiadania opowieści o doświadczeniu w wywiadzie) esencjalizacja płci (czyli wymiar: sex) jest pierwotną płaszczyzną utożsamienia dla osoby wypowiadającej opowieść, a więc poprzedza on inne, konstryktywistyczne utożsamienia płci społeczno-kulturowej [gender w wymiarach typu: wykształcenie, role instytucjonalne, autorstwo prac naukowych, etc. (Stoller 1968)].

${ }^{14}$ Kategoria gender jest uznawana w polskojęzycznych dyskursach humanistycznych za główną oś refleksji nad poetykami tekstów kultury, czyli to właśnie optyki genderowe różnicują od lat dwutysięcznych do dziś różnorodność ujęć badawczych zjawisk kulturowej tekstualizacji płci i to w ramach refleksji nad katagorią gender różnicują się główne pola badawcze we współczesnych badaniach nad tekstami kultury, w szczególności zaś w kulturoznawczo zorientowanym literaturoznawstwie. Dominują w tych krążących dyskursach genderowych różnorodne ujęcia konstruktywistyczne, akcentujące programowo swój antyesencjalizm (Łebkowska 2012: 367-407). 
jednostka integruje napięcie konfliktowe, niejako budując swój - alternatywny wobec społecznego konfliktu - porządek intymistycznego ładu jednostkowego doświadczenia. Taki eskapizm ocala jej porządek codzienności i jednocześnie przyczynia się do minimalizacji ryzyka społecznego udziału w konflikcie. W przypadku opowieści „aktorki” krainą eskapistycznej wędrówki w głąb siebie, na przekór rzeczywistości zewnętrznej (tu konflikt „Teatr”-„Wieš”), było jej utożsamienie z wiejską „artystką", która - poprzez sztukę - podlegała również mechanizmom lokalnego samowykluczenia, czyniąc doświadczenia estetyczne jedyną sferą codziennej samorealizacji. Świat społeczny Marii-„,artystki” był światem bez mężczyzn i bez angażowania się przez nią w społeczne sprawy wsi Gardzienice. Maria mieszkała samotnie $\mathrm{w}$ domu pełnym jej prac artystycznych i przestrzeń ta charakteryzowała się niezwykłą kobiecą ekspresją. Podczas moich wizyt u niej w lutym 2011 roku byłam naocznym świadkiem porządku jej egzystencji w symbolicznej przestrzeni haftowanych poduszek, malowanych przez nią własnoręcznie obrazów i misternych haftów oraz maryjnych ołtarzyków domowych udekorowanych kwiatami. Dzieła te znajdowały się we wszystkich przestrzeniach domu, łącznie ze spiżarnią. Tam, nad słoikami z przetworami, wisiała makatka ze złotą, wyszywaną papugą. Marię odwiedzały na co dzień wyłącznie kobiety z Gardzienic, przynoszące jej ciepłe posiłki i pomagające w codziennych pracach domowych. Kobieta-, ,artystka” z Gardzienic żyła wyłącznie sztuką i rozmowami z innymi kobietami z Gardzienic. Dla mnie syntetycznym symbolem jej intymistycznego świata jest do dziś poduszka, jak mówiła ona sama: ze „świerszczykiem”-„muzykantem”, którego wyhaftowała najpierw jako pojedynczy ornament, a następnie „dorobiła mu” łąkę i nuty. Motywy: łąki z kwiatami, świerszcza w kapeluszu „ze skrzypkami” i pięciolinią z kluczem wiolinowym opowiadała mi Maria (w dniu 21 lutego 2011 roku) jako swoistą autobiografię „świerszczyka”, któremu „pusto i smutno było żyć, więc wymyślił sobie muzykowanie na łące". Kontekst tej kobiecej intymizacji doświadczenia zaistniał także w opowieści „aktorki” jako wiejska, kobieca kraina cudowności, odległa od zewnętrznego świata lokalnego konfliktu, zapraszająca do chaty Marii - symbolicznej jaskini twórczej wolności kobiety.

Zewnętrzną, społeczną ramą narracyjną opowieści „aktorki” o jej doświadczeniu Gardzienic: „Wsi” w filtrze bycia „aktorką" z „Gardzienic”: „Teatru”, poprzedzającą intymistyczną figurę Marii, była - co istotne w strumieniu opowieści - dygresja o obawie przed ewentualnym odtworzeniem nagrania ${ }^{15}$ reżyserowi "Gardzienic" Włodzimierzowi Staniewskiemu. Co tu oczywiste, przed wywiadem standardowo poinformowałam moją rozmówczynię o ścisłej poufności danych, jednak pomimo to w trakcie wywiadu zaistniał symptomatyczny dialog, w którym nastąpiła sakralizacja wypowiadania/,,spowiadania” przez nią tej intymistycznej opowieści. Oto on:

${ }^{15}$ Oczywiście, uzyskałam pełną zgodę na wykorzystanie transkrypcji jako materiału badawczego i publikacyjnego. 


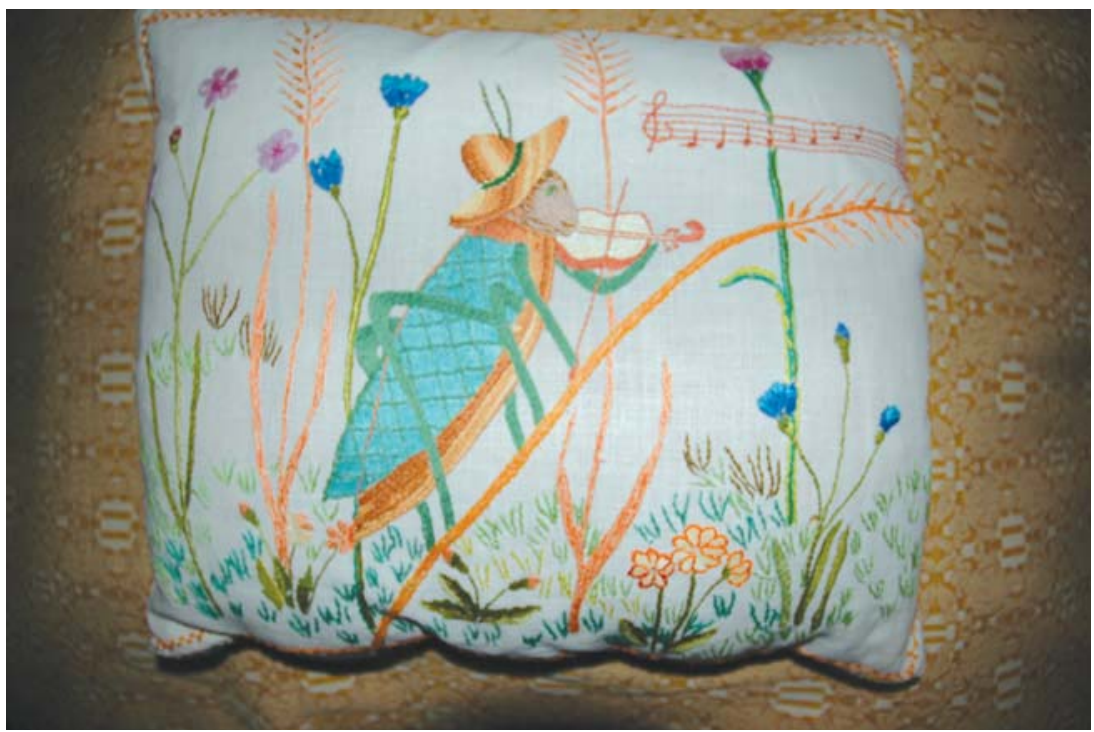

Fot. 1. Poduszka ręcznie wyszywana przez Marię według jej projektu (fot. A. Kapusta, luty 2011)

Kobieta: (...) Ja tutaj trafiłam dlatego, że usłyszałam o tym miejscu jako o „Teatrze”, jako o grupie ludzi, którzy robią fantastyczne sprawy, nie znałam Lubelszczyzny, nie znałam Wschodu Polski, nie wiedziałam, jak tutaj jest. Wpadłam tutaj jak śliwka w kompot od pierwszego dnia.

Anna Kapusta: A powiedz o swoim wejściu do „Teatru”.

K.: A nie puścisz tego panu Staniewskiemu?

A.K.: Nie puszczę panu Staniewskiemu, spokojnie.

K.: To jest bardzo kompromitująca historia, ponieważ...

A.K.: W ogóle nic nie puszczę panu Staniewskiemu, bo takie są moje zasady, poufność danych w antropologii jest kluczowa, tak jak w każdej nauce.

K.: Jak w porządnym konfesjonale.

A.K.: Tak. Z tym, że ja nie jestem księdzem.

K.: I nie dajesz rozgrzeszenia.

A.K.: Nie, każdy sobie sam musi udzielać.

K.: Bardzo dobrze. (...) (Kobieta 2012, wywiad)

Dopiero po tej symbolicznej ramie swoistego „ślubowania” badawczej „tajemnicy spowiedzi" kobieta wypowiedziała swoje doświadczenie kontaktu z Marią, kreując ową kobiecą przestrzeń wyłączoną z obszaru władzy symbolicznej reżysera. Symptomatycznie także ja jako kobieta słuchająca utożsamiona zostałam, pół żartem, pół serio, ale jednak: z instytucją religijną katolickiego konfesjonału. Wchodząc $w$ ten subdyskurs opowieści i podkreślając podmiotowość mojej rozmówczyni, wzmocniłam świadomie trajektorię jej kobiecej opowieści. Uznaję w tym miejscu za niezwykle znaczące, iż w społecznym spektrum lokalnego konfliktu figura reżysera, który „na pewno nie usłyszy”, w przestrzeni narracyjnej opowieści poprzedziła figurę Marii/Maryjki/Maryi. To domknięcie przestrzeni 
bez mężczyzn otwarło przestrzeń wyłączności dla kobiet jako spektrum wszelkiego rodzaju kreacji bez ograniczeń. Tak jak Maria: „artystka” otwierała swój świat intymistycznym zamknięciem się „na łączce świerszczyka - muzykanta”, tak i „aktorka” swą opowieść otwarła dopiero wtedy, kiedy domknęła swą obawę przed usłyszeniem jej przez reżysera. Internalizacja konfliktu społecznego nastąpiła, eksplodując w intymizacji opowieści. Gest powtórzenia izolacji Marii od zagrażającej męskości był w tej opowieści niezwykle radykalny.

\section{„Dziewczynka” i „Wieś”: kobiecość opowieści}

Opowieść o doświadczeniu spotkania „aktorki” z „artystką” Marią posiadała tak$\dot{z} e, \mathrm{w}$ przestrzeni narracyjnej udzielonego mi wywiadu, istotną ramę genderową symbolicznego powrotu kobiety do bycia marzącą dziewczynką. Ramę tę stanowiło więc symboliczne zrównanie „Wsi” Gardzienice ze zrealizowanym marzeniem „dziewczynki” o byciu częścią kobiecości „Wsi”. W ten to sposób kobiecość uosobiona w postaci Marii została przygotowana prefiguracją owej kobiecości „Wsi” w sposobie jej percypowania na wzór mitycznego obrazu spełnienia marzeń „małej dziewczynki”. Gardzienice w tej opowieści stają się kobiecą krainą i królestwem natury, w której na powrót „aktorka” zyskuje spontaniczność marzącej „dziewczynki”. Gardzienice urealniają utopię:

Kobieta: (...) Ja myślę, że [Gardzienice - przyp. A.K.] w pewnym sensie to jest dla mnie taka sfera marzeń. To jest to, co ja sobie wymyśliłam jako mała dziewczynka. (...) Ja zawsze jako dziewczynka urodzona w mieście marzyłam o tym, żeby mieszkać na wsi, nie wiem, skąd się to wzięło. Może dlatego, że gdzieś tam moi przodkowie, właściwie babciowie i dziadkowie z obu stron, $\mathrm{z}$ jednej strony z małego miasteczka pochodzą, z drugiej ze wsi i mam w tą stronę gdzieś we krwi ogromną nostalgię. To się chyba też łączy z jakimś rodzajem, nie wiem, czy można to tak patetycznie nazwać, ale patriotyzmu, bo ja zdaję sobie sprawę chyba coraz mocniej, że ja bardzo kocham tą ziemię, kocham nasz kraj, zachowując intencjonalnie chęć pozostania kosmopolitą, obywatelem świata, wyznawcą równości wszystkich ludzi i istot w ogóle, kocham to miejsce. I chociaż jest teraz trudno żyć w Polsce, ja tak uważam, że jest trudno i nie jestem chyba odosobniona w tym osądzie, nie chciałabym stąd wyemigrować, wyjechać po to, żeby mieć po prostu materialistycznie lepsze życie i tak dalej, kocham Polskę. Gardzienice są dla mnie faktycznie pewnym rodzajem utopii. (...) (Kobieta 2012, wywiad)

Utopia, o której mowa w powyższym fragmencie, jawi się „aktorce” jako uzewnętrzniona i zrealizowana marzeniem sfera: „serca”, „duszy”, „, intuicji” i „metafizyki meridianowo-energetyczno-kosmicznej”, przy czym „Teatr” i „Wieś” są w niej dwoma aspektami monistycznie przeżywanej, swoistej „natury Gardzienic”, ucieleśniającej radość odczuwania spełnionych marzeń:

Aktorka: (...) Czym są „Gardzienice” i Gardzienice? „Gardzienice” - „Teatr” i miejsce są w moim sercu, w mojej duszy, w mojej wizji i w moich oczach nierozdzielne. Oczywiście, to jest dla mnie wspaniała wizja stworzona przez pewnego człowieka, która przybrała formę w rzeczywistości 
w postaci spektakli, wydarzeń, koncertów, masy różnych inicjatyw, spotkań, wędrówek, wypraw, to wszystko się dzieje realistycznie, ale to jest sfera marzeń wydobyta z pewnej głowy nabitej wizjami. I oczywiście ten „Teatr” rozpłynął się, wylał się poza te mury z kamienia białego tutaj, który nas otacza, rozlał się po całym świecie, podróżował dużo, występował, wywarł na pewno jakiś wpływ na wielu ludzi, na wielu artystów, którzy tworzą jakieś swoje rzeczy. Na pewno sporo inspiracji wypłynęło stąd. No o tym zresztą się nawet pisze książki, więc faktycznie musi tego być dosyć dużo. Ale to marzenie jest bardzo mocno związane z tym miejscem, z tą ziemią. W książce, u Taranienki, Staniewski opowiada o tym, że to jest miejsce też wybrane poprzez intuicję, poprzez przewędrowanie wielu terenów tutaj po prostu upadł ten, ten kamień, który trzeba było podnieść, wypadł z kieszeni. Wiele spraw na wielu poziomach łącznie z takimi metafizycznymi meridianowymi, energiczno-promienno-kosmicznymi sprawami. To jest bardzo związane z tą ziemią, która nas tutaj sobie uprawia. (...) (Kobieta 2012, wywiad)

Warto zwrócić uwagę na ugruntowaną kulturowo - jako ciągle odradzający się konstrukt kobiecości $\mathrm{i}^{16}$ - intymistyczną retorykę „wylewania się,, „wyboru poprzez intuicję" oraz „bycia uprawianym przez ziemię”. „Teatr” tak przeżywany jest - w planie metaforycznym - niemalże rośliną i „wyrasta” on z ziemi Gardzienic, przynależąc do kategorii natury, nie zaś kultury. „Wieś” go symbolicznie naturalizuje i włącza w swój zmityzowany obieg przyrody. Ta mitologizacja „Wsi” jako „ziemi rodzącej” ludzi stanowi tło dla kobiecej inicjacji w gardzienickie bycie „aktorką," wyrażone także w ugruntowanej esencjalistycznie kobiecości, pojmowanej jako doświadczanie „trudu”, który zagraża „szaleństwem” każdej podejmującej go kobiecie: „artystce”. Moment „wyboru”: „Gardzienic”-, „Teatru” i Gardzienic-„Wsi”, równy porzuceniu innych scenariuszy życiowych karier i osobistych relacji poza Gardzienicami, opisywany jest w opowieści jako reintegrujące „aktorkę" uspokojenie, a zakorzenienie się w realiach „Wsi” i „Teatru” to inicjacyjna metafora życiodajnej „wylinki”. Świat poza Gardzienicami musiał zostać w niej symbolicznie i realnie odcięty, aby kobieta mogła stać się częścią procesu partycypacji w „naturze Gardzienic":

Aktorka: (...) [Wybór „Gardzienic” i Gardzienic - przyp. A.K.] To był potworny wysiłek emocjonalny i utrzymania zdrowia psychicznego, żeby wyskoczyć stąd, mając tylko trzy dni przerwy w pracy tutaj, zdążyć dojechać tam - jeden dzień trwa podróż w jedną stronę - przyjechać tam, zapomnieć to, co tutaj, całe to życie, tą intensywność, tą specyficzność, tam znormalnieć tudzież nabrać innego rodzaju specyficzności i zanim zrzuci się z siebie wszystkie te wylinki,

${ }^{16}$ Wszystkie wymienione tu elementy konstruktu esencjalistycznie ujmowanej kobiecości jako: „biernej”, „wtórnej”, „ucieleśnionej w związku z naturą”, partycypującej w „trudach rodzenia przez ziemię" stanowią chroniczny przedmiot debat krytyk feministycznych. Chroniczność ta wynika z trudnego statusu społecznego bycia biologiczną i kulturową kobietą (relacje sex-gender) we współczesnych społeczeństwach, jako że - relatywnie rzecz biorąc - samodecyzyjność cielesno-społeczna kobiet jest problemem (chronicznym procesem społecznym) niezwykle młodym historycznie, określanym zwykle jako modernistyczny dylemat emancypacji mieszczaństwa europejskiego. Dylematowi temu poświęcono tysiące wielojęzycznych pozycji bibliograficznych, odsyłam więc jedynie symbolicznie do znakomitej polskojęzycznej pracy Krystyny Kłosińskiej, jako że w polskim kontekście dyskursu naukowego jest ona jedyną autorką akademickiego podręcznika krytyki feministycznej (Kłosińska 2010: 70-73). 
natychmiast trzeba już z powrotem pędzić na dworzec, znowu jechać tutaj, będąc tutaj przez pięć dni, zrzucić wszystkie [nazwa miejscowości - kod. A.K.] i [nazwa miejscowości - kod. A.K.], i [nazwa miejscowości - kod. A.K.], i inne wylinki, i te wszystkie koszulki z siebie, wężowe skórki, e... bardzo trudne. (...) (Kobieta 2012, wywiad)

Powyższa retoryka inicjacji kobiecej wprowadza do tej esencjalizującej tradycji zrównania kobiety z porządkiem natury kategorię „wysiłku emocjonalnego i utrzymania zdrowia psychicznego" jako stanu poprzedzającego świadomą reintegrację. Ta właśnie kategoria trudnego inicjacyjnego „wysiłku” jest zapowiedzią wyboru estetyzującej „sztuki życia” jako codziennej „twórczości” i „aktorki”, i Marii „artystki” z Gardzienic. Kobiecość tej opowieści wyraża się w przekroczeniu retoryki esencjalizmu ową kategorią „wyboru”. Obie kobiety, czerpiąc twórcze inspiracje z bycia częścią kobiecości „Wsi”, wybrały autoekspresje poprzez sztukę. Fakt, iż w obu przypadkach sztuka ta była antysystemowa, bo nielegitymizowana dyplomami, nadał jej intymistyczny, inicjacyjny charakter, korespondujący jednakże z kobiecym samowykluczeniem $\mathrm{z}$ systemów definicyjnych, sankcjonowanych przez oficjalne dyskursy społeczne. Eskapistycznie: ani „aktorka” alternatywna, ani „artystka” ze wsi Gardzienice nie uczestniczyły w lokalnym konflikcie społecznym na linii „Gardzienice”-„Teatr” versus Gardzienice-„Wies”. Tak bowiem pracuje kobiecy eskapizm transformujący symbolicznie brak kobiecej, realnej decyzyjności - w estetyzację stylu życia. W planie społecznym tej reguły eskapizmu rzec by można: tam gdzie jest jawna esencjalizacja i estetyzacja kobiecości, tam czai się też milczący brak systemu decyzyjności kobiet.

\section{Figura indywidualnej intymizacji: proces społecznego utożsamienia}

Figura dyskursu społecznego Gardzienic w „Gardzienicach” w jego kobiecym, indywidualnym i intymistycznym wydaniu owocująca konstruktem symbolicznym Marii/Maryjki/Maryi narodziła się w narracyjnych ramach sytuacji społecznej wywiadu, w którym „aktorka” wypowiadająca swe doświadczenie dokonała podwójnego utożsamienia z esencjalistycznie konceptualizowaną przez nią kobiecością. Podstawową płaszczyzną tego społecznego utożsamienia była płeć biologiczna: „aktorki”, „artystki” z Gardzienic oraz moja. Opowieść kreująca spektrum symbolicznej kobiecości została więc ugruntowana biologicznie jako opowieść kobiety o kobiecości $i$ wobec kobiety. Kobiecość stanowiła w tym przypadku rudymentarną oś utożsamienia w opowieści (zob. schemat 1. Kobiecość. Społeczne wymiary utożsamienia). Wspólnym aspektem kobiecości, który zesencjalizowała „aktorka”-Opowiadaczka jako kobiecy: dla niej samej, Marii-„, artystki” oraz mnie - badaczki stała się więc płeć biologiczna. W tym wymiarze najsilniejszej, funkcjonalnej redukcji była poddana moja osoba, bo funkcjonowałam w sytuacji społecznej przeprowadzania tego wywiadu (relacja werbalna i niewerbalna 
„aktorki” wobec mnie) przede wszystkim jako kobieta, a dopiero w dalszej kolejności jako jej rówieśniczka i badaczka. Maria-,,artystka”, centrum opowieści w procesie utożsamienia wypowiadanego przez „aktorkę”, funkcjonowała - poza esencjalistyczną podstawą płci biologicznej - na dwu, konstruktywistycznych poziomach płci kulturowej jako: „artystka” i „bogini”. Twórczość jako styl życia była $\mathrm{w}$ opowieści codziennym wymiarem utożsamienia $\mathrm{z}$ kreatywną kobiecością („aktorka”-„, artystka”). Drugim aspektem genderowego utożsamienia okazało się aktywne doświadczenie osobistego sacrum bycia kobietą. $\mathrm{W}$ tym wymiarze Maria/Maryjka/Maryja stała się dla „aktorki” ucieleśnioną w realnej rzeczywistości wsi Gardzienice „boginią," z którą „aktorka” identyfikowała symbolicznie swe doświadczenia biograficzne.

Schemat 1. Kobiecość. Społeczne wymiary utożsamienia

\begin{tabular}{|c|c|c|c|}
\hline Aspekt kobiecości & Maria & Opowiadaczka & Badaczka \\
\hline płeć biologiczna & kobieta & kobieta & \multirow{2}{*}{ kobieta } \\
\hline twórczość & „artystka” & „aktorka” & \\
\hline duchowość & $\begin{array}{c}\text { bogini (Maryjka, } \\
\text { Maryja) }\end{array}$ & $\begin{array}{c}\text { poszukiwaczka } \\
\text { sacrum }\end{array}$ & \\
\hline
\end{tabular}

Źródło: opracowanie własne

Jak przedstawia to wizualizacja (schemat 1.): proces społecznego utożsamienia „aktorki” był podstawową osią konstrukcyjną dla zwerbalizowania indywidualnej figury intymizacji kobiecego dyskursu Gardzienic w "Gardzienicach”, czyli internalizacji konfliktu społecznego na linii „Teatr” versus „Wieś” w jego eskapistycznej intymizacji, a rudymentarny wymiar tego procesu ufundowało esencjalistyczne rozumienie kobiecości. Ten rudymentarny wymiar - biologicznie pojmowanej kobiecości został nadbudowany zgenderowanymi aspektami kobiecej „twórczości” i „duchowości”. Diagnozuję tę sytuację społeczną jako empiryczny wskaźnik kobiecego stylu konfliktowej regresji. Inaczej mówiąc, co warto tu wypunktować raz jeszcze: brak zewnętrznej decyzyjności w realnym konflikcie społecznym powoduje, że zamknięcie na wrogą i zagrażającą konfliktowo przestrzeń publiczną skutkuje reaktywacją esencjalistycznej kobiecości oraz - wtórnym wobec niej konstruowaniem symbolicznego świata intymizacji kobiecego doświadczenia. Rzec by można metaforycznie: płeć biologiczna ucieczki od realnego konfliktu jest tu kobietą i płeć kulturowa symbolicznej aktywności konstruowania intymistycznych światów zastępczych, wobec braku owego, realnego sprawstwa i decyzyjności jest tu - również - kobietą. Rzeczywistość człowieka jest bowiem zawsze społeczna i jeśli nie może on jej realnie i decyzyjnie przekształcać, to - jako mechanizm autointegracji - pozostaje mu rzeźbienie własnych światów wewnętrz- 
nych, w których wymuszona społecznie bierność staje się, mitologizowanym indywidualnie, wyborem autokreacji.

\section{„Święta Mario, łaskiś pełna” - struktura figury dyskursu (konteksty)}

Ostatnia fraza opowieści o Marii-„, artystce”, wypowiedziana przez „aktorkę” w wywiadzie, jest fragmentem chrześcijańskiej modlitwy Ave Maria, zwanej w Tradycji Pozdrowieniem Anielskim. „Aktorka” owo modlitewne pozdrowienie kieruje jednak nie do katolickiej Matki Boskiej, a do zmarłej Marii-,,artystki” z Gardzienic. To niezwykły przykład indywidualnej intymizacji dyskursu Gardzienic w „Gardzienicach”, wizualizujący ostatni element społecznego procesu werbalizacji, z którego wyłoniła się symboliczna figura Marii/Maryjki/Maryi, a więc wypowiadanej przez „aktorkę" esencjalnej kobiety i konstruktywistycznie dopowiadanej: „artystki” oraz osobistej patronki kobiecej duchowości mojej rozmówczyni. Figura ta możliwa była do identyfikacji jako analityczny i interpretacyjny fragment szerszego procesu społecznego, jakim jest ciągle żywy dyskurs Gardzienic i „Gardzienic”, „Wsi” i „Teatru” we wsi Gardzienice. Figura owa - w przestrzeni narracyjnej opowieści - posiada swą wewnętrzną strukturę symboliczną wizualizującą dwukrotną transformację Marii w Maryjkę i Marii w Maryję. Łącznie: obie te symboliczne metamorfozy manifestują pełny obraz biograficznego utożsamienia „aktorki” z „artystką”. Ważnym, bo najwcześniejszym chronologicznie: zarówno w porządku opowieści, jak i w gardzienickiej biografii „aktorki”, elementem tej struktury symbolicznej jest postrzeganie przez „aktorkę” realnej Marii jako obrazu „Wsi”-„,domu”. W opowieści najpierw ową charakterystykę „domu” zyskuje właśnie wieś Gardzienice. „Ja po prostu tutaj [do Gardzienic - przyp. A.K.] przyjechałam, ... i ... poczułam, że ja jestem w domu" - orzekła moja rozmówczyni. „Dom”-„Wieś” to także pierwszy, realny dom wynajmowany przez „aktorów” z „Gardzienic” w Gardzienicach. Tak mówiła o nim „aktorka”, dodając również w dalszej części, że dom to „korzeń” dla „Teatru” i centrum „energii”:

\footnotetext{
Aktorka: (...) I w tym domu mieszkali właściwie wszyscy po kolei przez te trzydzieści pięć lat, łącznie ze Staniewskim i jego żoną, i... i... po kolei naprawdę wszyscy jakiś tam mieli epizod w tym domu, w związku z czym on jest naprawdę, ezoterycznie mówiąc, dosyć napakowany specyficzną energią. (...) (Kobieta 2012, wywiad)
}

Następnie kwantyfikator symboliczny „domu”-„Wsi” zostaje przeniesiony na pierwszy obraz Marii, a w porządku narracyjnym opowieści Maria okazuje się również „domem” i „korzeniem”, osobowym centrum kobiecości wsi Gardzienice. Tak ją scharakteryzowała „aktorka”: 
Aktorka: (...) Niestety niedawno umarła najbliższa sąsiadka moja z tego domu [wynajmowanego przez „aktorkę” - przyp. A.K.] pani Maria [nazwisko - kod. A.K.], opowiadałam tobie wczoraj [badaczce - przyp. A.K.], która była kompletnym korzeniem, ona urodziła się dokładnie w domu, w którym przemieszkała całe życie. (...) (Kobieta 2012, wywiad)

Dom Marii-,,artystki” był także centrum kobiecości i matczyności, gdyż po jego utracie w pożarze pozostała ona w nim wraz z matką, potem dom odbudowano i dożyła w nim aż do śmierci:

Aktorka: (...) Był tutaj [w Gardzienicach - przyp. A.K.] ogromny pożar przerażający, który zadecydował o kształcie dzisiejszym tej wioski, ponieważ konkretnie przecedził domostwa, które tam się znajdowały bardzo gęsto. No i dom pani [nazwisko - kod. A.K.] spłonął doszczętnie oprócz pieca i komina. I ona została wraz z mamą na tym piecu i na tym kominie właściwie siedząc i wokół tego komina i tego pieca z pomocą, podejrzewam, sąsiadów odbudowano dom, w którym ona przeżyła całe życie, z którego się wyślizgnęła w listopadzie zeszłego roku. (...) (Kobieta 2012, wywiad)

W opowieści Maria jest zarazem metaforą i metonimią „Wsi”-„,domu”. Dom to miejsce jej kreatywności, cała jego realna oraz symboliczna przestrzeń ucieleśniająca siłę i twórczą kobiecość:

Aktorka: (...) U niej [u Marii - przyp. A.K.] pokój wypełniały łóżka, poduszki pod sufit, haftowane własnoręcznie, uszyte własnoręcznie. Pani Maria była artystką ludową, nie wiem, czy to można tak nazwać, czy to jest trafne, ona po prostu tworzyła, ona robiła masę rzeczy, malowała, malowała święte obrazy: Chrystusy, kościoły, malowała koniki polne, przeróżne rzeczy - co jej się nawinęło i co jej grało w duszy. No i w tym pokoju oprócz rzędów tych poduszek białych wykrochmalonych, cudownie wyprasowanych, zawsze czyściutkich, było mnóstwo kwiatów, które przez całą zimę kwitły, nie wiem, na skutek jakich czarów, kwitły posłusznie i Matki Boskie, wszechobecne figury Matek błękitnych, dobrych, przyjmujących wszystkich pod swoje skrzydła. No i widok zza okna, za oknem krowa należąca do sąsiadki. Ale to jest po prostu właśnie ta Polska. Ja kocham Wiesława Myśliwskiego, to, co on napisał. Uwielbiam pływać w tym jego świecie, który on tworzy. I dla mnie to jest tutaj, takie rzeczy, które on tam pisze, to wszystko jest tutaj, ci ludzie dokładnie tacy, takie piece w domu kaflowe, kuchnie, na których się gotuje i które grzeją, te krowy za oknem i te kwiaty, ale takie wiejskie, swojskie, te białe firanki, te Matki Boskie i te dzwony, no i majówka. Tutaj kobiety po prostu odstawiają taki obrzęd, taki rytuał w maju, rozstawiają sobie po prostu w świętym gaju - zawsze to się dzieje między drzewami - jest Matka Boska we wstążkach i kwiatach no i one siedzą, i dla niej śpiewają, godzinami i to się niesie po polach. (...) (Kobieta 2012, wywiad)

Tak wypowiadana kobiecość Marii jest jednocześnie kobiecością „Wsi”, w której uczestniczą inne gardzienickie kobiety, śpiewając „majówki”, czyli nabożeństwa katolickie odprawiane na cześć Najświętszej Marii Panny w miesiącu maju (Kamocki, Kubiena 2008: 163-164). „Aktorka” postrzega owe śpiewy jako gardzienicki „rytuał”, „obrzęd” i celebrację kobiecości kobiet ku czci kobiecości Matki Boskiej, będącej tu dla niej lokalną boginią kobiet („święty gaj”). Ten kontekst opowieści o Marii odsłania symboliczną ramę biograficznej identyfikacji „aktorki” z „artystką” z Gardzienic. Maria jest figurą symboliczną wcielonej kobiecości i jako taka bogini kobiecości wszystkich twórczych kobiet staje się znakiem 
ich autokreacji. Warto przy tym zwrócić uwagę, że dom Marii to wręcz świątynia „Matek Boskich” - „matek błękitnych”, którym cześć oddają kobiety w „majówkach”, a za oknem stojąca krowa dopełnia narracji o „Indiach w Gardzienicach”. Maria i jej dom w opowieści emanują kreatywną kobiecością „Wsi” i manifestują się życiową siłą kobiet gardzienickich. W tej estetyzacji doświadczenia „aktorka” odnajduje zrealizowane sacrum swej kreatywnej kobiecości, zapośredniczone także o jej wrażliwość literacką (twórczość Wiesława Myśliwskiego). Co interesujące: holistyczne, panteistyczne i monistyczne doświadczenie „Wsi” i jej kobiecości postrzegane jest przez „aktorkę" jako najwyższy wymiar patriotyzmu, pobrzmiewający charakterystyczną i znaną frazą z Wesela Stanisława Wyspiańskiego. „Aktorka” o osobistej mitologii kobiecości „Wsi” (o Gardzienicach i o Marii-„,artystce” z Gardzienic zarazem) powiedziała przecież: „ale to jest po prostu właśnie ta Polska”, zaś w Weselu Wyspiańskiego - symptomatycznie, w najbardziej chyba kanonicznym dla polskojęzycznego uniwersum symbolicznego mitologizacji wsi dialogu, to właśnie Poeta i „kobieta”: „wieś” (zesencjalizowana przez Poetę kobiecość), czyli wyrazicielka owej kobiecej „prawdy serca” - Panna Młoda, mówią o „sercu” i „polskości”, wizualizując je przy użyciu ciała Panny Młodej. Estetyzujący Poeta werbalizuje przecież kobiecość „wsi”, metaforyzując ją cielesnością kobiety, bo ową „Polskę” wypowiada Jagusia, dotykając, po sugestii takiego oto symbolicznego gestu Poety, własnej piersi:

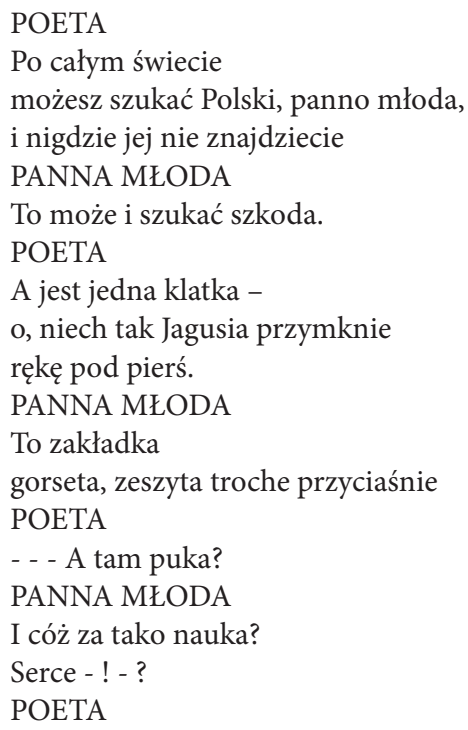

A to Polska właśnie.

Stanisław Wyspiański, Wesele, Akt III, Scena 16. (Wyspiański 1958: 189-190)17

Jak widać, estetyzacja kobiecości „wsi” idzie w parze z jej z korporalizacją i esencjalizacją.

\footnotetext{
17 [Podkreślenie w cytacie moje - A.K.].
} 


\section{Od Marii do Maryjki - duchowość i twórczość: akt pierwszy (bogini)}

Maria, realna kobieta ze wsi Gardzienice, w opowieści „aktorki” staje się boginią. Bogini ta jest kapłanką kobiecości: odprawia własne „msze”, śpiewa dla siebie samej pieśni maryjne, uczestniczy w gardzienickim kobiecym kulcie Maryjki ${ }^{18}$, a jednocześnie jest ona ucieleśnieniem lokalnych „Indii”. Wszystkie te charakterystyki, cytowane tu uprzednio w mottach, akcentują aktywność jako podstawową konstrukcję jej kobiecości. W intymnym świecie sztuki życia realna Maria sama jest Maryjką: boginią w błękitnych szatach i autorką prywatnych dzieł sztuki, które w jej domu oglądają prawie wyłącznie kobiety. Jej sztuka to sztuka życia duchowego, w którym czy to obraz, czy haft, czy pieśń są skierowane przede wszystkim do jej własnej kobiecości. Warto zwrócić uwagę, że „aktorka”, relacjonując obraz Marii jako Maryjki-bogini, podkreśla jej kreatywny, oryginalny aspekt bycia kobietą, gdyż odbiega on od symbolicznego stereotypu kobiety jako „wtórności, pasywności i chaosu"19, determinującego polskojęzyczne uniwersum kulturowe. Życie Marii-Maryjki jest komunikowaniem sobie samej własnej kobiecości bez

${ }^{18}$ Swoisty, ciągle i współcześnie żywy kult Maryjki-„,bogini” (to określenie z emicznego języka opowieści moich Rozmówczyń terenowych) na terenie wsi Gardzienice wymaga oddzielnego opracowania (szczegółowych, pogłębionych i empirycznych badań terenowych). W tym miejscu nadmienię tylko, że jest to (według moich własnych obserwacji) interesujący przejaw lokalnego, wiejskiego wydania sensualnej mariologii bez teologicznej chrystologii. Maryjka jest tu boginią niejako bez hierarchicznego kontekstu Kościoła katolickiego. Kobiety, w kobiecym gronie, śpiewają katolickie pieśni maryjne, niekiedy także pieśni na melodię pieśni maryjnych ze słowami ich własnego autorstwa. Spotykają się przy wiejskich kapliczkach Maryi, które same odnawiają, przystrajają kwiatami i celebrują w kobiecej wspólnocie. Przestrzenie te, kapliczki z ławeczkami, stanowią ich swoisty, intymistyczny wyłom kobiecy w wiejskiej przestrzeni publicznej. Jest to przestrzeń symbolicznej celebracji kobiecości, a Maryję w tej celebrze nazywają one Maryjką, czasem wręcz boginią. Towarzyszy temu atmosfera kobiecej przyjaźni.

${ }^{19}$ Por. Hasło: Kobieta autorstwa Władysława Kopalińskiego: Kobieta jest wcieleniem zasady negatywnej, pasywnej; symbolizuje Chaos, nieład; niezgodę; Księżyc; podświadomość; różnorodność; czystość, płodność, Ziemię, Matkę-Ziemię, matkę, macierzyństwo, miłość, opiekę; piękno; moralność, cnotę; pokusę, cudzołóstwo, rozpustę, intrygi, chytrość, kłamstwo; stałość; królestwo, naród, państwo, miasto, okręt; bałwochwalstwo; Kościół; Kościół, wyrocznię; ekstazę; niepewność; niebezpieczeństwo; okrucieństwo; krańcowość, wielomówność (Kopaliński 2001: 143). W przytoczonym zestawieniu uwidacznia się charakterystyczna, stała ambiwalencja kulturowego wartościowania kobiecości; z jednej strony podkreślająca wtórną, negatywną tożsamość kobiety, z drugiej - równie negatywnie - wartościująca jej aktywne aspekty („rozpusta”, „intrygi”, „chytrość” etc). W opowieści „aktorki” element androcentrycznej ambiwalencji kobiety nie występuje i Maria/ Maryjka jest wyłącznie kreatywną, aktywną i wspierającą kobiecością, z którą „aktorka” się utożsamia. Jako źródła kompendiów (słowników) symboli wybrałam prace Władysława Kopalińskiego, gdyż osadzone są one silnie w polskojęzycznym uniwersum językowo-kulturowym i dlatego uznaję je za adekwatne w polskim kontekście materiału terenowego, który prezentuję. Adekwatnie - dla polskojęzycznego materiału terenowego - reprodukują więc one polskie stereotypy symboliczne krążące w dyskursach. 
konieczności konfrontacji ze społecznym porządkiem „Wsi”, a podstawową formułą tego życia pozostaje sztuka autokreacji ukierunkowanej na swój własny odbiór. Tak właśnie - jako figurę kobiecej pełni - postrzega Marię „aktorka”. Maria to Maryjka, autosakralizująca się bogini, „ikona kompletna” i „samoubóstwienie”:

Aktorka: (...) Pani Maria z tym radyjkiem w okoleniu kwiatów, które w późniejszym etapie jej życia stały się sensem dla niej i ona stanowiła sama Marią będąc, ubierając się zawsze na błękitno - kolor, który kochała, po prostu w okoleniu tych kwiatów żywych, plastikowych, tych pieśni, to była jakaś ikona kompletna. (...) (Kobieta 2012, wywiad)

Maria to - dla „aktorki” - bogini kobiecej duchowości i twórczości. Jej codzienność była niezwykłym, inspirującym świętem sztuki adresowanej ad se ipsum. Opowieść prezentowana w analizowanym wywiadzie nie jest tylko metaforą, gdyż - faktycznie - funkcja autoekspresji była podstawową funkcją życiową Marii. Podczas moich wielokrotnych odwiedzin w jej domu (luty-maj 2011) zwróciłam uwagę, że estetyzacja jej przestrzeni życiowej (ciągłe dekorowanie domu kwiatami i eksponowanie prac jej autorstwa) oraz jej własny wizerunek stanowiły podstawowe zajęcia jej codzienności. Za każdym razem kiedy do niej (na jej zaproszenie: bezterminowe i już bez konkretnej zapowiedzi) przychodziłam, witała mnie ona opowieścią o którejś z jej prac. Maria posiadała także kilkadziesiąt różnych chust i apaszek, fartuchów i innych elementów codziennej garderoby, które starannie dobierała. Jej sposób bycia przywodził na myśl swoistą autokontemplację, ukierunkowaną jednak na interlokutorkę, bo to kobiety głównie odwiedzały ją w domu. Pamiętam, że kiedy się u niej pojawiłam pewnego dnia, najpierw bardzo dokładnie oglądała moje włosy, wręcz diagnozowała wzrokowo ich fizyczną strukturę, a następnie przyniosła mi jeden z wizerunków Jezusa Chrystusa, który sama namalowała, i orzekła, iż moje włosy „dobre by były dla Niego” (notatki terenowe: 21 lutego 2011 roku). Innym razem Maria zażyczyła sobie, żebym „coś zaśpiewała", i była niezwykle usatysfakcjonowana, że spełniłam jej prośbę (notatki terenowe: 26 lutego 2011 roku). Ten specyficzny sposób bycia Marii, znany mi z autopsji, w opowieści „aktorki” spowodował, że ów codzienny styl komunikacji „artystki” z Gardzienic wykreował niezwykły performans kobiecości wyłączonej z przestrzeni publicznej i aktualizującej swe wszystkie twórcze potencjały w intymistycznej przestrzeni kreatywnej kobiecości. Maria - jako osoba ludzka - była dla kobiet z „Gardzienic” ucieczką od stresogennej codzienności „Teatru”. W niej odnajdywały one esencjalną, kobiecą siłę tworzenia. $\mathrm{W}$ wielu rozmowach $\mathrm{z}$, aktorkami” Maria była po prostu zrealizowanym ideałem estetyzacji sztuki życia i swoiste "pielgrzymowanie” do samotnej chatki Marii przybierało niekiedy charakter parareligijnej peregrynacji do metaforycznych źródeł kobiecości. Samotna duchowość i twórczość Marii inspirowała kobiety do refleksji nad własną kobiecością i w tym sensie Maria-bogini była osobowym, inicjacyjnym centrum wsi Gardzienice dla wielu „aktorek”. Zwróciłam także uwage, iż żadna z moich, innych niż „aktorka” rozmówczyń, wspominająca o Marii, nigdy nie użyła w odniesieniu 
do niej deminutywnego określenia „boginka”20, zawsze mowa była o „bogini”. „Aktorka", której opowieść przytaczam, była bowiem tylko jedną z wielu rozmówczyń Marii, dla których ucieleśniała ona, esencjalistycznie pojmowaną, twórczą siłę kobiecości. Także i kobiety ze wsi Gardzienice wspomniały w wielu swobodnych rozmowach ze mną, że Maria corocznie organizowała dla nich specjalne uroczystości „na imieniny”, w trakcie których kobiecym spotkaniom towarzyszyły „śmiechy i nalewki”. Cały ten obraz Marii wykreował jej mitologizacyjny dyskurs twórczej duchowości kobiety, która żyjąc - poza wiejskim światem - ucieleśniała ową „czystą, esencjalną kobiecość kreacji”, jak to ujęła „aktorka” w wywiadzie ze mną. Tęsknota do takiego świata afirmacyjnej kobiecości dla kobiecości i na wyłączność kobiet wypełnia tę kobiecą figurę dyskursu Gardzienic w „Gardzienicach". Teatr tej kobiecej intymistyki stał się w owej kobiecej figurze konfliktowego dyskursu społecznego Gardzienic i „Gardzienic” wytchnieniem od „Teatru”, „Wsi” i ucieczką od traum realnych biografii.

\section{Od Marii do Maryi - wniebowstąpienie i odcieleśnienie: akt drugi („apokryf")}

Drugim, finalnym składnikiem figury dyskursu Gardzienic w „Gardzienicach”, czyli dynamicznym elementem symbolicznej figury Marii/Maryjki/Maryi, jest jej druga metamorfoza, a więc Maria/Maryja, ostatni etap symbolicznej biografii Marii, „artystki” z Gardzienic. W opowieści „aktorki” transformacja Marii w Maryję przybiera postać symptomatycznego ustnego „apokryfu”21 o przemia-

${ }^{20}$ Co interesujące: w polskojęzycznym uniwersum symbolicznym forma „boginka” (deminutywna forma od „bogini”) wprowadza zawsze ambiwalentny aspekt „bogini”, co udało się dobrze uchwycić Władysławowi Kopalińskiemu. W haśle słownikowym Boginka diagnozuje on następująco tę tradycję symbolizacji: „Boginka, bogunka, mamuna, dziwożona, mit. słow. nazwa demonów wodnych (wodnic, rusałek), leśnych i polnych, szpetnych i mściwych, ponętnych i kusicielskich" (Kopaliński 2003: 117).

Warto zwrócić uwagę, że powyższe: ambiwalentne aspekty „boginki” („szpetność”, „mściwość, „ponętność” i „kusicielskość”) są kategoriami relacji ukierunkowanymi na rywalizację kobiet o uwagę mężczyzn. Inaczej mówiąc: jeśli zaakcentować - w opisywanym przypadku Marii jako bogini - jej kobiecość ukierunkowaną autotelicznie na kobiecość własną i kobiecość innych kobiet, bez jej odbioru przez mężczyzn i oceny przez męskie wspólnoty, zrozumiałe stanie się dostrzeganie wyłącznie jej pozytywnego wizerunku przez „aktorkę” wypowiadającą opowieść. W tym sensie Maria jest tu boginią kobiecości, autoteliczną i samozwrotną siłą kreacji dostępnej wszystkim kobietom.

${ }^{21}$ Pojęcia „apokryf” używam w jego szerokim znaczeniu, mając tu na myśli swoisty antykanon dla dominujących dyskursów społecznych, symboliczny „tekst ukryty”, a w tym przypadku relację ukrytą po dwakroć, bo to gardzienicka opowieść istniejąca wyłącznie w ustnym, intymistycznym przekazie, do którego dotarłam. Opowieść „aktorki” prezentująca przemianę Marii w Maryję: „święty obraz” jest, według mnie, apokryfem kobiecości ukrytym w lokalnym konflikcie społecznym na linii „Teatr” - „Wieś”. Traktując całą opowieść w ramach wywiadu jako pełnoprawny tekst kultury, w omówieniu jej fragmentu o Marii/Maryi, przyjmuję literaturoznawczą definicję apokryfu, 
nie „artystki” we wniebowstępującą Marię - Maryję: „święty obraz”. Przytoczę raz jeszcze in extenso obraz wniebowstąpienia Marii/Maryi, by wyodrębnić jego dwa kluczowe filary:

Kobieta: (...) Historię o pani Marii, bo warto. Pani [Imię i nazwisko - kod. A.K.] w maju zeszłego roku zaczęła się robić półprzezroczysta pomalutku. To wszystko odbywało się w atmosferze niezwykle pięknej sielanki: właśnie te majowe, niedziele przecudownie okraszone słońcem, spokojem, brzęczącymi owadami ponad łąką, nad którą ona mieszkała. Siedząc na krzesełku przed swoim domem, widząc tą łąkę, oglądając każdego dnia, ona zaczęła robić się przezroczysta i to, my już instynktownie czuliśmy, że ona umiera, ale ona była tak cudownie rozkochana i zachwycona tym stanem, że to było coś bardzo natchnionego i bardzo napawającego bezpieczeństwem. I nie zapomnę tego obrazu, kiedy ona ubrana w błękitny fartuch w ogromne białe grochy szła przez łąkę w blasku słońca, przez łąkę przekwitniętych dmuchawców - białych kulek puchatych, puszystych jak te grochy na tym jej błękitnym fartuchu, z błękitem nieba ponad nią i z tym puchem siwych włosów ściętych na mniszka. I ja patrząc na nią, zdałam sobie sprawę, że ona, ta Maria idąca przez łąkę tych dmuchawców, latawców, wiatrów, ona idzie do nieba, ona jest już przezroczysta, ona jest błękitna, ona jest już leciutka jak ten mniszek lekarski. I ona szła przez tą łąkę w stronę mojego domu, mniszki przed... przed jej stopami ulatywały do nieba i leciały, i ona szła tak lekko, tak pięknie, taka szczęśliwa, rozpuszczając się w poranku tej majowej niedzieli. To był absolutnie święty obraz, Święta Mario, łaskiś pełna. (...) (Kobieta 2012, wywiad)

Pierwszym filarem owego „apokryfu” Marii wniebowstępującej jest charakterystyczny spektakl jej spokojnego, „sielankowego”, intymistycznego umierania. Umieranie to okazuje się jej cielesnym zanikaniem, stopniowym odcieleśnianiem ciała realnej kobiety ${ }^{22}$ na rzecz bezcielesnego przebóstwienia w obraz „Świętej”, „łaski pełnej Maryi” i jak to zostało wypowiedziane w opowieści: Maria „robi się przezroczysta”. Maria - niejako nie traci tu więc kobiecego, ziemskiego ciała, tylko stopniowo znika, blaknąc w słońcu majowej łąki. Maria - rozpuszcza się cieleśnie w kobiecej naturze majowej łąki. Nawet jej umieranie - w oczach „aktorki” - uobecnia artystowskie dzieło sztuki życia, stając się kobiecym ars moriendi. To umieranie jest pełnią i spokojem: samozachwytem, rozpłynięciem się i rozpuszczeniem w przestrzeni majowej łąki. W szerokiej perspektywie długiego trwania autokontemplacyjna przemiana ciała w kwiat przywodzi na myśl inicja-

sformułowaną przez Marię Adamczyk: „Termin «apokryf» (z gr. apókryphos, od czasownika apokrýpto - ukrywać) oznacza tekst, księgę ukrytą, schowaną, usuniętą, tajemną, niezrozumiałą czy niewiadomego pochodzenia. (...)" (Adamczyk 2002: 46).

22 Oddzielnym zagadnieniem szczegółowym jest swoiście wyparta i symbolicznie zaprzeczona cielesność Marii „artystki” z Gardzienic, którą werbalizuje w opowieści „aktorka” z „Gardzienic”. Maria, i jako Maryjka, i jako Maryja jawi się przecież w przytoczonej opowieści de facto jako kobieta bez fizycznego ciała. Ten głęboki problem artystowskiego zaprzeczania kobiecej cielesności w gardzienickiej opowieści zasługuje na odrębne opracowanie i pogłębioną interpretację. Kobieca cielesność i jej tekstowe reprezentacje stanowią kluczowe zagadnienia dla refleksji w ramach tak zwanego feminizmu korporalnego, akcentującego wskaźnikowość kulturowego statusu kobiecego ciała jako rewersu społecznych dyskursów społecznego opresjonowania i autorepresjonowania się kobiet (Hyży 2003). 
cyjny wymiar mitu Narcyza ${ }^{23}$, choć w tym przypadku mowa o mniszku lekarskim. Niemniej jednak schemat przemiany doczesnego ciała człowieka w wiecznie odradzający się kwiat jest wspólny i sygnuje on zawsze społeczny dyskurs estetycznego samowykluczenia przebóstwionego mitycznie bohatera. W tym sensie ów narcyzm samowykluczenia w sztuce autokontemplacji sygnuje śmierć społeczną jednostki żyjącej w ekskluzywnej relacji własnych praktyk estetycznych.

Drugim filarem owego gardzienickiego „apokryfu” Marii/Maryi jest „święty obraz" jej wniebowstąpienia. Maria, w błękicie i bieli, w błękitnym fartuchu w białe grochy, w synestezyjnej wyobraźni „aktorki” staje się jednocześnie mniszkiem lekarskim i wniebowstępującą Matką Boską. Obraz mniszka lekarskiego w jego ostatniej fazie cyklu rozwojowego, a więc $\mathrm{w}$ momencie gdy białe kule rozsypują się pod wpływem wiatru, to swoista figura kobiecej pełni Marii-,,artystki”, wszak roztrącana przez wiatr biała kula to zbiornik nasion rośliny, a więc i jej śmierć jest także początkiem życia dla nowych roślin. Biała kula niesiona wiatrem, rozpadając się, rozplemnia życie nowych mniszków. „Maria”, istota „leciutka jak mniszek lekarski", sama jest więc rozpadającym się ciałem rośliny, a zarazem domyślnym pomnożeniem kreacji. „Aktorka” wypowiada w opowieści jej inicjacyjny fantazmat pełni: „I ja, patrząc na nią, zdałam sobie sprawę, że ona, ta Maria idąca przez łąkę tych dmuchawców, latawców, wiatrów, ona idzie do nieba, ona jest już przezroczysta, ona jest błękitna, ona jest już leciutka jak ten mniszek lekarski”. Metaforyczna postać Marii - dojrzałego mniszka lekarskiego, unoszonego wiatrem, jawi się w tym imaginacyjnym obrazie, a zarazem i relacji z rzeczywistego, biograficznego doświadczenia „aktorki”, metonimią przemiany kwiatu w puch, rozpadu kwiatu w życiodajne nasiona dla nowych roślin, będące tu metonimią fizycznej śmierci Marii. Maria „rozpuszcza się" przecież w majowej, kobieco-kwietnej życiodajności wiejskiej łąki. Co interesujące: w tym imaginacyjno-apokryficznym obrazie pojawia się najpierw popkulturowy kryptocytat z popowego przeboju lat 80., czyli utworu w wykonaniu Urszuli Dmuchawce, latawce wiatr ${ }^{24}$, a dopiero potem następuje puenta w postaci Marii/Maryi, przywołania owego „świętego obrazu”, dopowiedzianego ostatecznie modlitwą Ave Maria. Co jeszcze bardziej interesujące: w owym gardzienickim „apokryfie” Marii/Maryi Maria wbrew katolickiemu dogmatowi nie dostępuje łaski wniebowzięcia, a samodzielnie: idąc przez łąkę na własnych nogach: wniebowstępuje. To istotne przekształcenie symboliczne, gdyż w tym wydaniu Maria/Maryja jest aktywną, ziemską kobiecością wniebowstępu-

${ }^{23}$ Na temat inicjacyjnej tradycji odczytywania mitu Narcyza - zob. Tomasz Sikora (2004: 186$-200)$.

${ }^{24}$ Dmuchawce, latawce, wiatr, słowa: Marek Dutkiewicz, muzyka: Romuald Lipko, wykonanie: Urszula (1983). Porównując słowa tego przeboju lat 80. ubiegłego wieku i konstrukcję symboliczną opowieści „aktorki”, zwróciłam uwagę na następujące podobieństwa pomiędzy słowami utworu i opowieści „aktorki”: 1. relacje tworzone z punktu widzenia doświadczeń kobiety, 2. obraz inicjacyjny łąki (wraz z dojrzałymi, białymi dmuchawcami), 3. w obu przypadkach „kobieta idzie po niebie”, a „świat z betonu jest daleko". Reasumując: obraz łąki jako inicjacyjnej kobiecości jest wspólny dla obu werbalizacji, zarówno w popkulturowym tekście utworu, jak i w owym „apokryfie”. 
jącą, w przeciwieństwie do pasywności ${ }^{25}$ katolickiej Matki Boskiej, która jedynie dostępuje owego wniebowzięcia. Katolicki dogmat o Najświętszej Marii Pannie, mówiący o Królowej Nieba, Jej Zaśnięciu i Wniebowzięciu, pochodzi z 1950 roku i tak oto współczesna mariologia objaśnia eklezjologicznie jego przesłanie:

(...) Wydanie tego dogmatu nastąpiło [uzupełnienie - A.K.] w dniu 1 listopada 1950 roku [w] bulli papieskiej Munificentissimus Deus. W pełnym powagi tekście, noszącym pieczęć nieomylności papieskiej zadekretowanej na Soborze Watykańskim Pierwszym, wiara we wniebowzięcie Maryi Dziewicy, od dawna uznawana za prawdziwą wśród wiernych i teologów, została promulgowana jako dogmat Kościoła Rzymskokatolickiego przez papieża Piusa XII: Niepokalana Matka Boga, Maryja zawsze Dziewica [semper Virgo], po zakończeniu życia z duszą i ciałem została wzięta do chwały niebieskiej (Pelikan 2012: 187-188).

W gardzienickiej opowieści rodzi się spontaniczny kobiecy „apokryf” aktywnej, samostanowiącej o własnym akcie umierania Marii/Maryi. Wspólnym polem dla opowieści „aktorki” i katolickiej ortodoksji jest niejako monistyczna wizja „duszy i ciała” Marii/Maryi, wraz z którymi wprost z ziemi trafia ona do nieba. W opowieści ta droga do nieba odbywa się w pełnej świadomości, bez zaśnięcia i bez łaski Boga. Maria, wraz z białymi kulami dojrzałych mniszków, po prostu rozpuszcza się w łące i tak idzie do nieba. Gardzienicki „apokryf” powstał poza ortodoksją Kościoła katolickiego, w którym „aktorka” nie uczestniczy, jednak paradoksalnie reprodukuje i on odcieleśnienie kobiety dostępującej nieba. Ubóstwiona kobiecość wyrzeka się i tu swej cielesności.

\section{Mowa zastępcza: indywidualna figura lokalnego konfliktu społecznego (konkluzja)}

Figura intymizacji Gardzienic w kobiecym dyskursie „Gardzienic” w analizowanej opowieści „aktorki” z „Gardzienic” ukształtowana jest przez intymistyczne doświadczenie realnej i symbolicznej biografii Marii - „artystki” z Gardzienic. Maria staje się w tej opowieści boginią Maryjką i Matką Boską, uosabia ona kobiecość „Wsi”. Opowieść o Marii/Maryjce/Maryi stanowi przykład kobiecej autokreacji jako sposobu eskapizmu społecznego w obliczu lokalnego konfliktu na linii „Teatr”-„Wieś”, na który żadna z kobiet nie miała realnego wpływu. Sposobem na artystyczny rozwój obok tego konfliktu, ale także i innych konfliktogennych jakości społecznych, czyli wspólną płaszczyzną dla utożsamienia się „aktorki” $\mathrm{z}$ „artystką”, była specyficzna duchowość kobieca, życie sztuką i autokreacją. Rzec

${ }^{25} \mathrm{Na}$ gruncie teologii katolickiej „pasywność” jest paradoksalnie mistyczną aktywnością, gotowością „przyjmowania daru” zarówno przez Najświętszą Marię Pannę, jak i przez mające ją naśladować kobiety. Jest ona traktowana jako esencjalna charakterystyka kobiecości w Boskim Planie Stworzenia, nie używa się więc w żadnym kontekście świeckiego pojęcia pasywności, nazywając tę postawę teologicznie: kobiecą „receptywnością” (Kupczak 2013: 55-119). 
by można: wobec braku sprawstwa i wpływu na zewnętrzny, realny świat społeczny, kobiety zbudowały swój wewnętrzny, imaginacyjny świat społeczny. Ten świat społeczny - poprzez negację zewnętrznych reguł gry konfliktowej - odsłania przed badaczem społecznym niezaspokojone potrzeby pełnej samorealizacji kobiet: pragnienie estetycznej ekspresji, docenianie ich jako holistyczny sposób na życie, poszanowanie dla ich codziennego procesu twórczego oraz wiele innych jakości kobiecych, wykluczonych ze spektrum konfliktu gardzienickiego, ale i - szerzej - jest to aktywne poszukiwanie zestawu wartości kobiecego tworzenia, niemożliwych do harmonijnej realizacji w lokalnej społeczności. Sztuka tej kobiecej autoafirmacji jest obrazowana w opowieści jako autokontemplacja i autokreacja utożsamiana $\mathrm{z}$ rozwojem duchowym poprzez twórczość. Ta estetyczna miniaturyzacja przestrzeni życiowej kobiet jest też sposobem na asekuracyjne samowykluczenie, doświadczane przez kobiety w systemach hierarchicznych męskiej władzy. Kobiety, wobec braku decyzyjności i sprawstwa, ulegają samopomniejszaniu, chowają się w mikroświatach intymistycznych autokreacji i zanikają społecznie, wypchnięte z przestrzeni publicznej konfliktu. Za Krystyną Kłosińską trzeba by tu stwierdzić, że kobiety w swej mowie zastępczej autokreacji i estetyzacji stylów życia ucieczkowo „czytają i piszą kulturę miniaturami” (Kłosińska 2006). Ten stary schemat kulturowy eskapizmu estetycznego zaistniał także w analizowanej opowieści. Zaistniał tu jednak progresywnie. Poprzez ową progresywność rozumiem skoncentrowanie tegoż estetycznego samowykluczenia społecznego, tak widocznego w biografii Marii z Gardzienic, poprzez ukierunkowanie go na jej samorozwój, aktywność twórczą niebędącą celowym i czekającym na odpowiedź komunikatem do społeczeństwa, a autokomunikacją jej autotelicznej wartości swoistego artystowskiego zrównania życia i sztuki. Maria-,,artystka”, symbolicznie wypisując się z androcentrycznych ładów „Wsi”, rodziny i konfliktu z „Teatrem”, zbudowała wyraziście pozytywną tożsamość kobiecą i udało jej się stworzyć maksymalnie feminocentryczny świat społeczny ${ }^{26}$, enklawę przyjazną i otwartą dla kobiet. Dlatego właśnie „aktorki” z Gardzienic i kobiety z Gardzienic tak łatwo utożsamiały się idealizacyjnie z siłą jej kobiecości. Maria wypracowała swój własny model emocjonalności i kreacyjności w ramach relacji interpersonalnych, afirmujący kobiecość i maksymalizujący kobiece jakości jej własnej indywidualności oraz pragnienie kobiecej wspólnoty. Jej artystowski gest wycięcia się z porządków światów społecznych innych niż jej własna wizja intymistycznej mikrospołeczności kobiet maksymalizował, powtórzę tu raz jeszcze: feminocentryczność kobiecej kreacji. Maria była kobietą kobiecości dla kobiet i w owym getcie gardzienickiej kobiecości kobiety odnajdywały azyl dla swych niezrealizowanych na zewnątrz potrzeb: kobiecej duchowości: akceptującej i synkretycznej, inkluzywnej dla religijnych i ateistycznych postaw kobiet, kobiecej kreacyjności życia codziennego i kobiecej sztuki szczegółu doświadczania świata, wpisanego w kobiecy wymiar

${ }^{26}$ Ten feminocentryzm jest niezwykle „ekofeministyczny” w swej wymowie, kreuje on bowiem ekologię kobiecości. O projektach ekofeministycznych - zob. Marzena Jakubczak (2004: 27-40). 
„Wsi”. I wprawdzie w tej „świątyni kobiecości” świat społecznego konfliktu został przemilczany, ale jednak uwaga skupiona była na jego odbiorczyniach, nie na zewnętrznych kryteriach maskulinizacji konfliktu „Teatru” i „Wsi”.

Figura Marii/Maryjki/Maryi jest - w strumieniu dyskursu Gardzienic w „Gardzienicach” - symboliczną mową zastępczą wobec milczenia „aktorki” o konflikcie na linii „Teatr” - „Wieš". Ta mowa wykwita estetycznym dziełem niepisanego poematu lirycznego o Marii-„, artystce” z Gardzienic, z którą symbolicznie utożsamiła się „aktorka”. Maria w opowieści żyje sztuką życia, rozwija się duchowo i artystycznie, ale jednocześnie nie ma wpływu na świat społeczny „Wsi”, nie uczestniczy w żadnych instytucjonalnych porządkach. Owo estetyczne samowykluczenie to jej autokontemplacyjny trud budowy alternatywnego świata afirmacyjnej kobiecości. Nadal jednak jest to świat alternatywny, choć świat bez dogmatów teologicznych i doktryn estetycznych, bez hierarchów i reżyserów. Nadal ten świat wymaga jednak od twórczej kobiety, w imię samorealizacji, samowykluczenia i ucieczki w fantazmaty, bo nadal konflikt społeczny jest męski, a ucieczka w intymistykę kobieca. Maria z Gardzienic zmarła, pozostawiając po sobie nieuporządkowaną kolekcję jej intymnych światów sztuki. Żyje ona w opowieściach kobiet mitologią swej esencjalnej kobiecości. To ona, Maria/Maryjka/Maryja jest uosobieniem samoakceptującej się, twórczej kobiecości. To ona jest w Gardzienicach żywą opowieścią o doświadczaniu przez kobiety kobiecości Gardzienic i „Gardzienic”: „Wsi” i „Teatru” i ona wyraża dla owych kobiet spersonalizowaną przypowieść kobiet dla kobiet o ucieczce w sztukę kobiecości. Poza opowieścią i przypowieścią Maria nie istnieje. Żyje jedynie w ustnych relacjach kobiet. Jeden z „apokryfów” tej kobiecości ofiarowała mi w akcie zaufania „aktorka” z „Gardzienic”. Maria/Maryjka/Maryja jest w nim bezkolizyjnie i boginią, i Matką Boską. Jako esencja sztuki kobiecości.

\section{Bibliografia}

Adamczyk M.

2002 Hasto: Apokryf, w: Słownik literatury staropolskiej, red. T. Michałowska, Wrocław-Warszawa-Kraków, s. 46.

Burzyńska A., Markowski M.P.

2006 Teorie literatury XX wieku. Podręcznik, Kraków.

Giddens A.

2007 Przemiany intymności. Seksualnossć, miłość i erotyzm we wspótczesnych społeczeństwach, przeł. A. Szulżycka, Warszawa.

Hyży E.

2003 Kobieta. Ciało. Tożsamość. Teorie podmiotu w filozofii feministycznej końca XX wieku, Kraków.

Jakubczak M.

2004 Relacje kobieta - natura w debacie ekofeministycznej, w: Gender. Konteksty, red. M. Radkiewicz, Kraków, s. 27-40. 
Kapusta A.

2013 „Człowiek gardzienicki” - sceny z życia fantazmatu, „Anthropos”, nr 20/21, s. 165-188; http://www.anthropos.us.edu.pl/texty/kapusta.htm (dostęp: 01.12.2017).

Kapusta A.

2015 Diabeł gardzienicki: diabeł opowieści. Proces opowiadania jako figura dyskursu społecznego, „Studia Humanistyczne AGH”, t. 14/1, s. 99-118.

Kamocki J., Kubiena J.

2008 Polski rok obrzędowy, Kraków.

Kłosińska K.

2006 Miniatury. Czytanie i pisanie „kobiece”, Katowice.

Kłosińska K.

2010 Feministyczna krytyka literacka, Katowice.

Kopaliński W.

2001 Słownik symboli, Warszawa.

2003 Słownik mitów i tradycji kultury, Warszawa.

Kupczak J. OP.

2013 Teologiczna semantyka płci, Kraków.

Łebkowska A.

2012 Gender, w: Kulturowa teoria literatury. Główne pojęcia i problemy, red. M.P. Markowski, R. Nycz, Kraków, s. 367-407.

Leszczyńska K., Pasek Z. (red.)

2008 Nowa duchowość w społeczeństwach monokulturowych i pluralistycznych, Kraków.

Pelikan J.

2012 Maryja przez wieki, przeł. J. Pociej, Kraków.

Rappaport R.

2007 Rytuał i religia w rozwoju ludzkości, przeł. A. Musiał, T. Sikora, A. Szyjewski, Kraków.

Sikora T.

2004 EUOI. Studia z symbolizmu i metaforyzacji katoptrycznej, Kraków.

Stoller R.

1968 Sex and gender: on the Development of Masculinity and Feminity, London.

Szyjewski A.

2008 Etnologia religii, Kraków.

Wyspiański S.

1958 Wesele, w: tegoż, Dzieła zebrane, t. 4, Kraków, red. pod kierownictwem Leona Płoszewskiego, Kraków, s. 189-196. 